\title{
Prediction of Monsoon Rain for the Year 2018 for Marathawada India
}

\author{
Anand M. Sharan* \\ Mechanical Engineering Department, Faculty of Engineering, Memorial University of Newfoundland, ST. John'S, Newfoundland, Canada A1B \\ 3X5; FAX: (709) 864 - 4042
}

Received 05 March 2018, Accepted 08 May 2018, Available online 12 May 2018, Vol.8, No.3 (May/June 2018)

\begin{abstract}
In this work the rainfall in Marathawada, an area with extremely small amount of rain has been calculated based on rainfall data of last 32 years going back to 1986. The calculations have been performed using the Time Series method and Fast Fourier Transform (FFT) method. In the first method, statistical regression analysis has been carried out whereas in the second method, the rain pattern is fitted with Fourier periodic analysis. The results of these two methods are averaged for better reliability. The rainfall data is further analyzed using rainfall spectrum analysis.
\end{abstract}

Keywords: Monsoon rain prediction, Annual rainfall, Rainfall frequency spectrum, Flood control, Hydro-power generation

\section{Introduction}

Water crisis in India- depletion of water: In India about 75 to $90 \%$ of the annual rainfall takes place in Monsoon season. Here, the rain water is needed for agriculture as 40 percent of the cultivated area is irrigated. India's 70 percent of the irrigated area is used for food crops to meet the needs of the growing population. The need for water is so large that the rainfall rarely meets the need and it results in depletion of $\mathrm{w}$ water reserves. In 1998, the groundwater, one of the forms of reserves had its utilization 38 percent, which increased to 58 percent in 2009.

If we look at the water reserves of India, it is in the form of (a) stored water in ponds, lakes, (b) those in flowing rivers plus (c) in form of snow or ice on the Himalayas'. Another availability is in form of groundwater. If the rainfall is not enough, one would have to dig into the reserves which have limits.

Water is needed for agriculture, city supplies including drinking, power generation, as well as in many industrial processes. The only new source or input is the rain-water.

Therefore, it is critical that the study on rainfall be made. The present study has been undertaken to analyze water shortage due to insufficient rainfall in India's one of the most drought prone areas.

As far as agriculture is concerned, lack of rain results in large number of farmers committing suicides ((Telangana's shocking..., 2014; How Telangana farmer's ..., 2014; Telangana government ..., 2014;

*Corresponding author's ORCID ID: 0000-0003-1336-8333 DOI: https://doi.org/10.14741/ijcet/v.8.3.7
Farmer's suicide ..., 2009; Farmers' suicides ..., 2012; Four farmers ..., 2017; Three farmers ..., 2012). Water shortage studies can also be seen in ((India is already ..., 2015; In Gujarat's water ... 2018; Water shortage ..., 2018; Gujarat staring ..., 2018; Water scarcity ...,2018; India's escalating ... , 2015; India's potable ... , 2016; India's fast-growing ..., 2015; Groundwater recharge,2008)). Water shortage also affects the hydropower generation (The thirst for ..., 2016).

One way to avoid farmer's suicides would be - if possible, come up with a model to predict monsoon rainfall in advance so that the farmers, and various governments at different levels, be prepared from before about the amount of rainfall in the Monsoon season (total new water). This way, the farmers can decide what to plant and how much to plant? The farmers are under heavy loans and a drought breaks their backs. In case of advance knowledge about a drought -it will help farmers in avoiding loans.

In the present study, the prediction is based on 32 year rainfall history of an area. Separate studies are done for separate areas as it has been found that in many cases a distance as little as 100 kilometer can lead to entirely different rain pattern.

It is therefore very desirable if one can have an idea of coming year's rainfall amount. This will help in planning of sowing of the crop in agriculture or storing water in dams etc. Similarly one can plan for relief supplies for drought affected areas. In case of excess rains one can prepare for flood. Such predictions have been tried out by others.

This present method can also help in planning of hydro-electric power generation where generating companies can plan ahead. This method's results can also be used in planning for dangers of flood. This is 
because dams have been built on rivers and their tributaries and if there is heavy rain over the catchment area then water from all the dams need to be released from time to time to avoid over-flooding in the dams. The simultaneous release of water from many dams causes flood in areas downstream.

\section{Analysis of Historical data and predictions}

Fig. 1 shows the location of Marathawada in Western India. One can see the results for months of June to September in Figs 2 to 5 respectively and that of the total values (sum of all these four values) in Fig. 6.

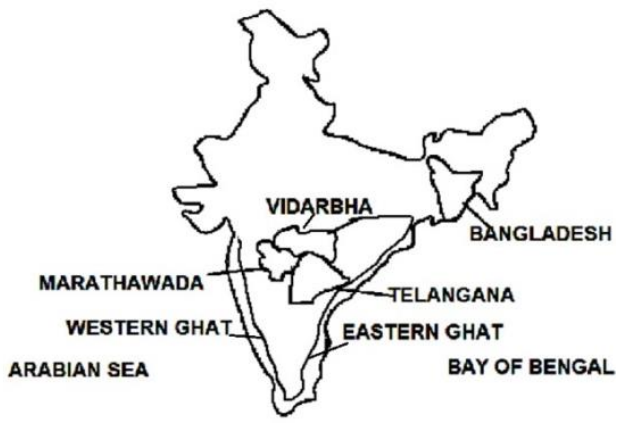

Fig.1 Location of Marathawada Vidarbha and Telangana between western and eastern Ghats
In Fig. 2 we see that there is a decreasing trend in the rainfall amount. Most of the time, the actual rain has been below the regression line but lately, the rain amounts lie close to it. The predictions for 2018 for June by both methods are not very far apart. To predict for 2018 Monsoon season, the prediction is based on the average of these two values which have been arrived at independently. The summary of results is given in Table 1 . Yearly rain data is published in (Monsoon, 2018)

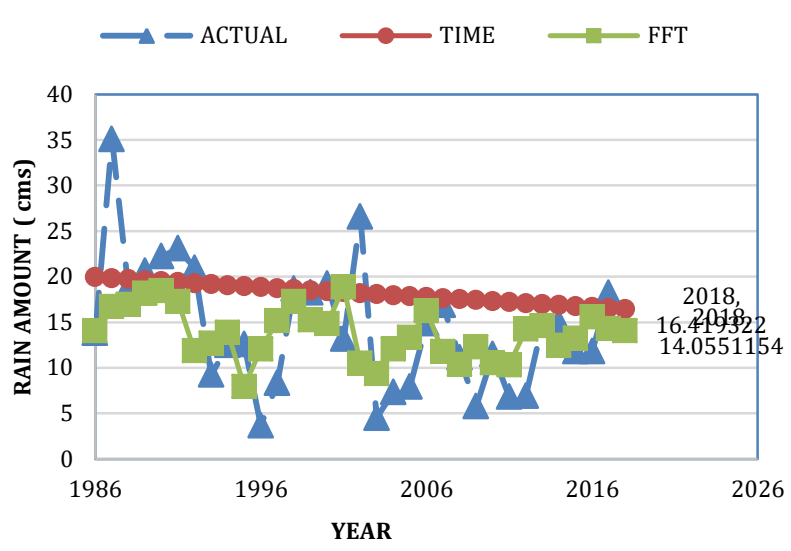

Fig. 2 Rainfall amount in month of June

Table 1: Rain forecast in centimeters for Marathawada during 2018 monsoon months

\begin{tabular}{|c|c|c|c|c|c|c|c|}
\hline Method & Year & June & July & Aug & Sept & Total & Comments \\
\hline Time series & 2018 & 16.4 & 13.4 & 18.0 & 17.5 & 65.3 & \\
\hline Fast fourier transform (FFT) & 2018 & 14.1 & 10.7 & 20.8 & 13.1 & 63.4 & \\
\hline $\begin{array}{c}\text { Prediction- average of time } \\
\text { series and FFT methods }\end{array}$ & 2018 & 15.2 & 12.0 & 19.4 & 15.3 & 64.4 & $\begin{array}{c}\text { Normal but below } \\
\text { average }\end{array}$ \\
\hline Average of 32 yars & & $\mathbf{1 3 . 6}$ & $\mathbf{1 9 . 6}$ & $\mathbf{1 8 . 3}$ & $\mathbf{1 7 . 4}$ & $\mathbf{6 8 . 9}$ & \\
\hline
\end{tabular}

There are other scientists who also publish their scientific works and their analysis can be seen in (Singh, P, and Borah, B., 2013; Delsole, T. and Shukla, J., 2012; Gadgil, S and Srinivasan J. 2012). The details about these two methods can be seen in (Excel - Time Series Forecasting, 2013; Frequency Domain Using Excel, 2005).

Fig. 3 shows the rainfall for the month of July. Even here the trend is decreasing and that the rainfall amount predicted for this month is even lower than that of June.

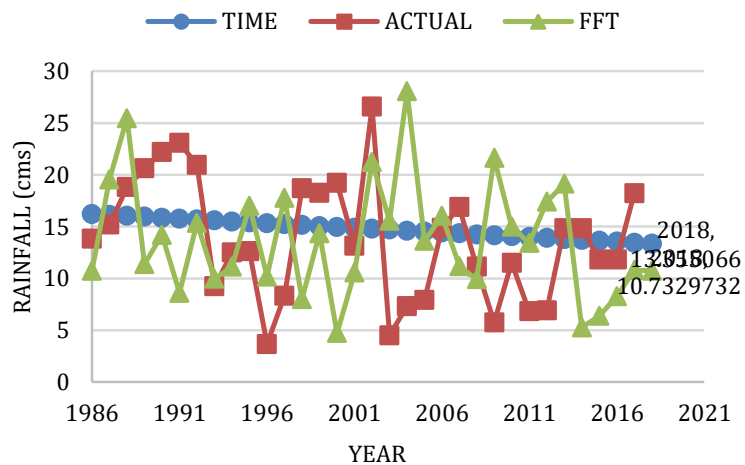

Fig. 3 Rainfall in July
In the recent past, the rainfalls have been excessively low. They show wide fluctuations from year to year.

In Fig. 4 we see the same decreasing trend. The predicted rain is more than that of June. The rainfall history for September is shown in Fig. 5. The amount of rain still is higher than July.

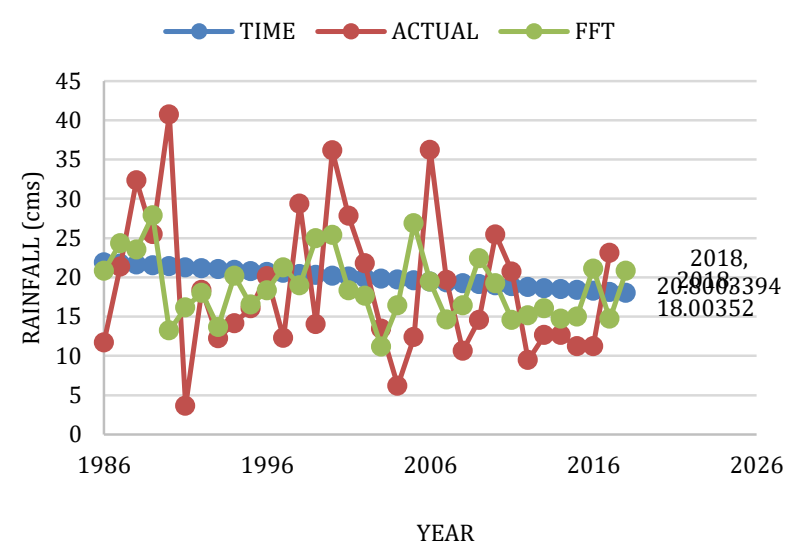

Fig. 4 Rainfall in August 


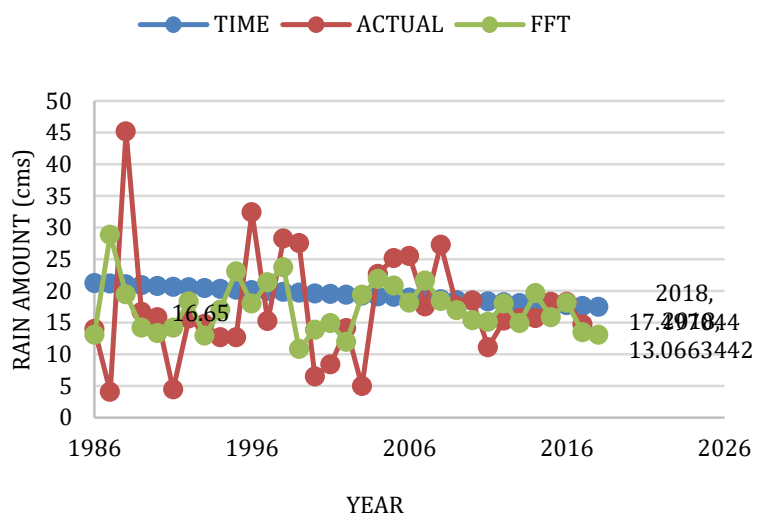

Fig 5 Rain amount in September

In Fig. 6, the actual rainfall values of different months were added up as total rain. The results were obtained as before. The predicted results by two methods are quite close.

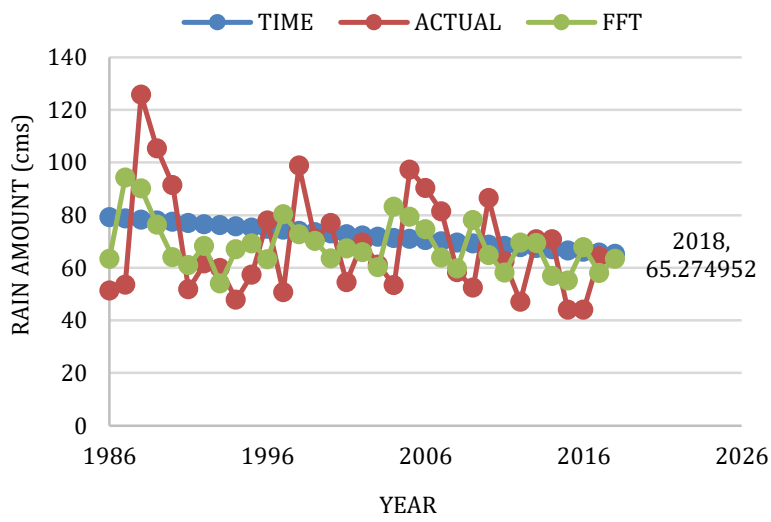

Fig. 6 Total Rain In Marathawada In 2018 Monsoon Period

Fig. 7 is a plot of amplitudes versus frequency numbers based on the results of Fourier analysis. Here, we see that frequency numbers 2, 3, 4, 9 and 13 have significant amplitudes close to 2 centimeters. All of the amplitudes have been calculated using the Fourier series. The fast variation of total rainfall from year to year is due to the presence of many significant frequencies.

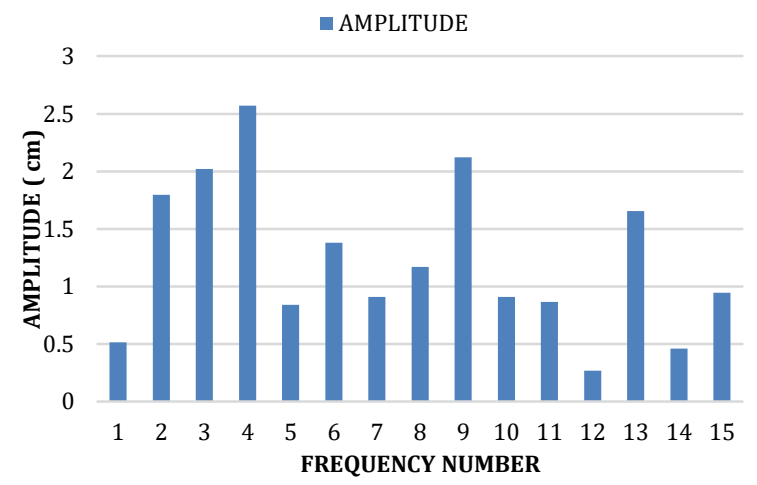

Fig. 7 Amplitude versus frequency number

\section{Conclusions}

In this work, at first a brief review of the water reserves were carried out. From these it was determined that the total reserve depends upon one input which is rainfall in India. If the rainfall is less then it is bound to affect all users but in short run mainly the farmers. It was seen that lack of rain affects many different aspects of life such as droughts, famines, flooding, agricultural production and hydro power generation

Based on this work one can conclude the following:

1) The historical rain data showed that Marathawada has had slight decreasing trend in rainfall (Time Series method).

2) The FFT method quite reasonably maps the actual rainfall data in most cases even though the rain pattern is quite complicated.

3) The complicated and fast changing rainfall pattern arises due to the presence of several significant frequencies.

4) In the coming year, the rain amount is slightly less than the average of 32 years (Table 1 )

\section{References}

Telangana's shocking statistics: 350 farmer suicides in five months, 2014, http://www.ndtv.com/ article/south/ telangana-s-shocking-statistics-350-farmer-suicides-infive-months-616371

How Telangana farmer's suicide has changed the world of his daughter, 2014,

http://www.ndtv.com/article/south/how-telangana-farmers-suicide-has-changed-the-world-of-his-daughter-572462

Telangana government feels the heat after farmers' suicide, 2014, http://www.khaleejtimes.com/ kt-articledisplay1.asp?xfile=data/international $/ 2014 /$ November/in ternational_November605.xml\&section=international

Farmer's suicide in Vidarbha : Everybody's concern , 2009, http://medind.nic.in/jaw/t09/i2/jawt09i2piii.pdf

Farmers' suicides in the Vidarbha region of Maharashtra, India a qualitative exploration of their causes, 2012, http://www.ncbi.nlm.nih.gov/pmc/articles/PMC3291283 /

Four farmers end life, one lights own pyre in Nashik, 2017 , https://timesofindia.indiatimes.com/city/nashik/4-

farmers- end- life-one-lights-own-pyre-in-maharashtra/ articleshow/59261660.cms

Three farmers commit suicide in draught-hit Marathwada region, 2012, http://zeenews.india.com /news /maharashtra/ three-farmers-commit-suicide-in-draughthit-marathwada-region_1508366.html

India is already facing a water crisis-and it is only going to get worse, 2015, https://thediplomat.com/ 2014/04/indias-worsening-water-crisis/

In Gujarat's water crisis, key question: why is Narmada's level low this year?, 2018,http://indianexpress.com/ article/explained/in-gujarats-water-crisis-key-questionwhy-is-narmadas-level-low-this-year-5113688/

Water shortage in Gujarat's Morbi forces people to dig holes in the ground, 2018, http://indianexpress.com/photos/ india-news/gujarat-morbi-water-crisis-narmada-river5119373/ 
Gujarat staring at water crisis this summer, 2018, http://indianexpress.com/article/india/gujarat-staring-atwater-crisis-this-summer-5042137/

Water scarcity threat to India and South Africa - Climate News Network,2018, https:// climatenewsnetwork.net/ 23742-2/

India's escalating water crisis, https://www.livemint.com > Politics > Policy India's potable water crisis is set to worsen , 2016, https://www.livemint.com > Politics > Policy India's fast-growing cities face water crisis - Phys.org, 2015, https://phys.org > Earth > Environment Groundwater Recharge,2008,

https://en.wikipedia.org/wiki/Groundwater_recharge
The Thirst for Power: Hydroelectricity in a Water Crisis World, 2016, http://www.brinknews.com/the-thirst-forpower-hydroelectricity-in-a-water-crisis-world/

Monsoon, 2018, http://www.imd.gov.in/ pages/ monsoon_main.php/

Singh, P, and Borah, B., 2013, "Indian summer monsoon rainfall prediction using artificial neural network", Stoch Environ Res Risk Assess Vol 27:pp. 1585-1599

Delsole, T. and Shukla, J., Geophys. Res. Lett., 2012, http://dx.doi.org/10.1029/ 2012GL051279.

Gadgil, S and Srinivasan J. 2012, "Monsoon prediction: are dynamical models getting better than statistical models?", J Current Science vol. 103, NO. 3, 10 August 2012

Excel - Time Series Forecasting, 2013, http://www.youtube. $\mathrm{com} /$ watch? $\mathrm{v}=\mathrm{gHdYEZA50KE}$

Frequency Domain using Excel, 2005, http://online. sfsu.edu/jtai/downloads/ENGR\%20302/Excel.FFT.pdf 